\title{
Strategic Management of Agribusiness: Determinants and Trends
}

\author{
Chao-Chien Chen ${ }^{1}$, Hsiu-Ping Yueh ${ }^{2}$ \\ and Chaoyun Liang ${ }^{3}$
}

\begin{abstract}
Intense changes have arisen in global agriculture, yielding a new market reality that is more complex and competitive than before. To confront these changes, a renewed perspective on the practice of agribusiness management is necessary. However, studies in this critical line of research are scant. This study updated the outlook on the strategic management of agribusiness in Taiwan by conducting in-depth interviews with 10 expert agrientrepreneurs. The results indicated that agribusiness strategies can be categorised as targeting one of three dimensions: the external environment, the internal environment, and sustainable development. This paper discusses each dimension in detail and suggests five broader trends of strategic management.
\end{abstract}

Keywords: agribusiness, agribusiness entrepreneurs, strategic management, sustainable development.

\section{INTRODUCTION}

Over the past three decades, dramatic structural changes have occurred in agriculture worldwide as a result of globalisation, economic liberalisation, environmental regulation, rapidly shifting societies, and reduced protection of agricultural markets that are increasingly complex and competitive (Boehlje, Doehring \& Sonka, 2005). These changes direct the emergence of new customer bases and consumption behaviour patterns for agricultural supply manufacturers, distributors, and retailers. To properly confront these changes, a new perspective on the strategic management of agribusiness is necessary. Strategy typically refers to the ability of an organisation to position itself in the market in a way that best suits its resources and competences. Actual business conditions require prompt adaptation strategies (i.e., strategic

1 Chao-Chien Chen, Doctoral Student, Department of Bio-Industry Communication and Development, National Taiwan University, No. 1, Sec. 4, Roosevelt Road, Taipei, 10617, Taiwan. E-mail: d02630002@ntu.edu.tw; markchen1204@gmail.com. 2 Hsiu-Ping Yueh, Professor, Department of Bio-Industry Communication and Development, National Taiwan University, No. 1, Sec. 4, Roosevelt Road, Taipei, 10617, Taiwan.E-mail: yueh@ntu.edu.tw.

3 Chaoyun Liang, Professor, Corresponding author, Department of Bio-Industry Communication and Development, National Taiwan University, No. 1, Sec. 4, Roosevelt Road, Taipei, 10617, Taiwan. E-mail: cliang@ntu.edu.tw. 
management) that suit dramatic changes, especially in the agricultural sector (Rankin, Gray, Boehljec \& Alexander, 2011; Rogers \& Caswell, 1988).

Accordingly, three critical strategic considerations should be examined in agribusiness: (1) managerial decisions must be made in an environment of increasing risk and uncertainty, (2) developing and adopting technology and new innovations is critical to long-term financial success, and (3) responding to changes in industry structure, the competition landscape, and industry boundaries is essential to maintaining market position (Boehlje, Roucan-Kane \& Bröring, 2011). In essence, the strategic decisions of agribusiness managers must be based on internal considerations of costs, technology, risks, financial planning, and managerial resources, as well as external considerations of synergies, differentiation, market positioning, and marketing strategies. In addition, Rankin et al. (2011) suggested that the sustainability dimension of strategies deserves specific attention when discussing the strategic management of agribusiness.

Agribusiness managers are usually sensitive to their financial position, government environmental regulations, the bargaining power of their customers, and the identification of product rivals (Westgren, Sonka \& Litzenberg, 1988). However, the aforementioned changes indicate an urgent need to update the managerial practices of agribusiness operators, which increasingly must include principles of entrepreneurship (McElwee, 2008). This necessitates a revisiting of the strategic management of agribusiness, particularly in Asia-Pacific countries where agriculture has a crucial role in the socioeconomic fabric. Nevertheless, academic studies in this area have been limited to date. This manuscript reports the results of such a research effort and analyses the resulting new perspective on the strategic management practices of expert agrientrepreneurs in Taiwan. We hope that these brief but critical research findings can generate unique academic and practical contributions.

\section{LITERATURE REVIEW}

\section{Strategic management for agribusiness}

Academic research into strategic management dates to the 1950s. The focus of strategic management has shifted from business policy to competitive advantage and finally to corporate governance. Strategic management has also been transformed from focusing on long-range planning, five-force analysis, strategic advantage, core competency, and blue ocean strategy to incorporating flexible corporate strategies appropriate for the rapidly changing modern environment (Financial Times, 2015). Earlier studies of 
agribusiness management (e.g., Rogers \& Caswell, 1988; Westgren \& Cook, 1986) have indicated that agricultural researchers have ample opportunities to contribute to the area of strategic management, and these studies have urged meaningful, timely, and applicable research in this critical field.

Strategic management is defined as the process of examining both present and future environments, formulating an organisation's objectives, and making, implementing, and controlling decisions focused on achieving these objectives in present and future environments (Smith, Arnold \& Bizzell, 1985). Strategic management can also be defined as the process of managing the pursuit of organisational goals while managing the relationship of an organisation to its environment (Higgins \& Vincze, 1993). Dess, Lumpkin, and Taylor (2005) held that strategic management comprises the analysis, decisions, and actions that an organisation executes to create and sustain competitive advantages; in other words, strategic management involves the formulation and implementation of major goals and initiatives by a company's top management on behalf of the company's owners.

Nag, Hambrick, and Chen (2007) indicated that a company's goals and initiatives are formulated and implemented according to the consideration of resources and an assessment of the internal and external environments in which the organisation competes. Academics and corporate managers have developed numerous models to assist in strategic decision making in the context of complex environments and competitive dynamics (Ghemawat, 2002; Westgren \& Cook, 1986). These models, including Pearce and Robinson's strategic management model, Porter's forces driving industry competition, the BCG growth-share matrix, and the McKinsey model for business portfolios, have all suggested that both internal and external environments should be considered.

In light of the structural changes in agriculture resulting from climate change and urbanisation trends, the requirements for new entrants, innovation, and social entrepreneurship have become clear. Agricultural practitioners increasingly require entrepreneurship, in addition to sound management and craftsmanship, to be sustainable in the future (McElwee, 2008). On the basis of the aforementioned studies, agricultural attributes, and global sustainability, Rankin et al. (2011) indicated that the strategic management of agribusiness must consider the dimension of sustainability. Therefore, the following literature review is divided into three parts: the external environment, the internal environment, and sustainable development. 


\section{External environment}

Traditionally, strategic management models have identified the main elements of external environments as including: the general economy, the regulatory environment, customer markets, competition, suppliers, labourers, and technology (Dess et al., 2005; Smith et al., 1985). Westgren et al. (1988) identified several external environments that should be considered in agribusiness management, namely the general business environment, industry trends, analysis of competitors, and potential industry entrants. In addition to the domestic market, international agricultural policies critically influence agribusiness performance (Kennedy, Harrison \& Piedra, 1998). Determinants of agricultural export performance may include environmental factors (e.g., hostility and price competition), aspects of export competitive advantage (e.g., firm export competence, export channel knowledge, product adaptation, competitive price, and distributor support), and channel relationship antecedents (e.g., information exchange and cooperation) (Karelakis, Mattas \& Chryssochoidis, 2008).

Government policy is usually a double-edged sword, creating both advantages and disadvantages for agribusiness. Harling (1994) concluded that government protection is finite, and that business strategies appropriate when a market is protected can be inappropriate when protection is removed. Hartwich and Negro (2010) showed that governments support innovation initiatives through various funding schemes that do not explicitly foster collaboration. Rosairo, Lyne, Martin, and Moore (2012) further indicated that agribusiness management problems may increase if governments do not plan to facilitate their policies.

The capacity of agribusinesses to respond to changes in industry structure, the competitor landscape, and industry boundaries is essential to maintaining market position (Dobson, 1992). Empirical results suggested that the strategies of product development applied by successful agribusinesses are the key to their faster growth relative to competitors (Giannakas \& Tzouvelekas, 1998). In addition to research and development (R\&D) investment and the risk of failure, agribusiness product-innovation strategies mainly depend on competitors' counterstrategies (Russo, Cardillo \& Perito, 2003).

Traditionally, most agricultural firms are family businesses in which family interactions must be incorporated into agribusiness operations (Heiman, Just, McWilliams \& Zilberman, 2001). Nowadays, the role of diverse social networks as strategic resources should be noted when considering the external environment of agribusiness management. These networks are created by farmers in various forms for their mutual benefit, such as strategic alliances, joint ventures, partnerships, integration, cooperatives, and value chains. The proper operation of these social networks not only allows farmers 
to manage and customise their production according to consumer needs but also helps farmers achieve scale economies, reduce transaction costs, accelerate information gathering, share R\&D outcomes, expand distribution channels, and eventually promote industrial status (Amanor-Boadu, Marletta \& Biere, 2009; Bhuyan, 2005; De Moura, Martin \& Mollenkopf, 2009; Gall \& Schroder, 2006).

In summary, the critical external environmental factors for the strategic management of agribusiness are: the general business environment, agroindustrial trends, government policy, international and domestic competition, potential industry entrants, the supply chain, distribution channels, and family interactions.

\section{Internal environment}

The main elements of the internal environment identified by the strategic management literature typically include: business functions (marketing, finance and accounting, production and operation, human resources, R\&D, and management information systems), the value chain, and business portfolios (Dess et al., 2005; Smith et al., 1985). Among the critical issues raised by the agribusiness literature, strategic positioning and goal setting are frequently mentioned. These actions are crucial in helping agribusinesses confront structural change in the industry (Goldsmith \& Gow, 2005). Westgren et al. (1988) indicated that agribusinesses with formal planning systems are relatively more concerned with future financial performance, whereas firms with informal planning systems focus more on current measures of financial position. Westgren et al. indicated that product-oriented firms are more sensitive to the potential for identifying new markets than are commodityoriented firms. In addition, Baker and Leidecker (2001) suggested that the use of a mission statement, long-term goals, and ongoing evaluation are heavily emphasised by high-performing agribusiness.

Providing a quality product can be considered the most essential service of an agribusiness. Russo, Cardillo, and Perito (2003) emphasised the critical roles of R\&D investment and the risk of failure in product-innovation strategies. Capitanio, Coppola, and Pascucci (2010) suggested that the capacity to build relationships in product markets is the determinant of product innovation, and that the territorial context determines the relevance of each driving factor of innovation. Liu, Kemp, Jongsma, Huang, Dons, and Omta (2014) further argued that integrative capabilities play a crucial role in innovation novelty, which enhances product superiority, and in improving functional capabilities and gaining market potential. In addition, Gellynck, Cárdenas, Pieniak, and Verbeke (2015) confirmed that trust and innovative 
entrepreneurial orientation influence farmers' absorptive capacity, and that innovative entrepreneurial orientation influences agribusiness performance.

Marketing is another critical aspect of agribusiness management. A previous study showed that market-oriented agribusinesses are highly innovative and achieve superior performance (Micheels \& Gow, 2008). A well-balanced marketing plan emphasises overall superiority, and must be designed for both retailers and consumers (Hsu \& Wann, 2004). Vertical coordination mechanisms must be installed in the marketing plan, leading to competition among retail chains and thus ensuring quality and building brand equity (Hanf \& Kühl, 2005). Moreover, prior research has indicated that store atmosphere, customer service, and product quality are the main marketing factors that influence customer satisfaction regarding agrifood retailing (LülfsBaden, Spiller, Zühlsdorf \& Mellin, 2008). Although many farmers have strong marketing preferences associated with traditional spot markets, scholars and practitioners have urged that Internet strategies should be adopted in a supply-distribution management framework (Henderson, Dooley, Akridge \& Carerre, 2005), particularly the use of social media and customer relationship management systems for agrifood retailing (House, House \& Mullady, 2008; Torres, Jr., Akridge, Gray, Boehlje \& Widdows, 2007).

Furthermore, the performance of other aspects of management is also crucial for agribusiness. For example, Harling (1988) indicated that agribusinesses with high returns on assets have more diversified product lines, are superior at controlling general expenses, and have fewer assets. Baker, Starbird, and Harling (1994) determined that factors critical to successfully managing quality in agro-industry are top management, the role of the quality department, employee relations, employee training, and process management. Martinez and Poole (2004) suggested that a move towards flexibility and adopting an entrepreneurial style are both likely to contribute to improved agribusiness performance. In addition, Henderson et al. (2005) indicated that Internet strategies are more likely to be adopted in larger firms with a global scope.

In summary, the critical internal environmental factors for the strategic management of agribusiness include: goal setting, strategic positioning, quality product, service innovation, marketing management, vertical coordination, customer service, top management, employee relations, cost control, and financial management.

\section{Sustainable development}

In the past 20 years, numerous agricultural studies have focused on sustainable development (Hansford, Cary \& Coath, 2003; Horrigan, Lawrence 
\& Walker, 2002; Thompson, 2007). The sustainability of the agrifood system and farming as a multifunctional enterprise is of increasing importance. Häni, Pintér, and Herren (2007) indicated that successful short- and longterm adaptation to endogenous and exogenous, biotic and abiotic, and social and economic forces requires access to information and indicators on the current situation as well as possible future trends in the ecological, social, and economic domains of sustainability. Lubell, Hillis, and Hoffman (2011) reported that a central goal of most sustainable agriculture programmes is to encourage growers to adopt practices that jointly provide economic, ecological, and social benefits.

Previous studies have developed various tools for measuring the concept of agricultural sustainability. For example, Zahm, Viaux, Girardin, Vilain, and Mouchet (2007) proposed the French indicateurs de durabilité des exploitations agricoles (IDEA) method, which covers 16 objectives: coherence, biodiversity, soil preservation, water preservation, atmosphere, product quality, ethics, local development, landscape preservation, citizenship, the management of non-renewable natural resources, human development, quality of life, adaptability, employment, and animal well-being. Häni, Stämpfli, Gerber, Porsche, Thalmann, and Studer (2007) proposed the RISE (response-inducing sustainability evaluation) model, which contains 12 indicators covering ecological (natural resources and their management), economic, and social aspects fundamental to the sustainability of agricultural production. The natural resources aspect comprises energy, water, soil, and biodiversity; the management aspect comprises emission potential, plant protection, and waste; the economic aspect comprises economic stability, economic efficiency, and the local economy; and the social aspect comprises working conditions and social security.

From the perspective of agribusiness, Lubell et al. (2011) suggested that cooperation, innovation, and knowledge gaps are likely to be relevant for the resilience and sustainability of numerous types of socioecological systems. Rankin et al. (2011) determined that strong management pressures have a substantial relationship with the level of an agribusiness's sustainability initiatives. Other pressures include competition, government regulations, the media, the company's primary function, and company size. Furthermore, Ross, Pandey, and Ross (2015) indicated that agribusinesses may transition their sustainability initiatives to focus on internal initiatives that address environmental and supply chain concerns over time. From the perspective of consumption, Nasir and Karakaya (2014) determined that socially responsible, health-oriented, utilitarian, and hedonic consumption patterns are significant predictors of intention to purchase organic foods. In addition, environmental 
responsibility could act as a moderating factor between socially responsible consumption behaviour and intention to purchase.

\section{METHOD}

\section{Participants and procedures}

Because of the preliminary nature of the current study, a qualitative method was adopted for exploring the strategic management of Taiwanese agribusiness. The research participants did not allow us to conduct a detailed investigation into their professional lives to study their managerial practices. Therefore, we adopted a semi-structured interviewing method rather than a case study approach. According to Cohen and Crabtree (2006), semi-structured interviews are preceded by informal and unstructured interviews to allow researchers to develop a deep understanding of the topic of interest, which aids in formulating relevant and meaningful questions. In this study, semi-structured in-depth interviews were conducted with 10 expert agrientrepreneurs in Taiwan. Prior to each interview, we invited the participants to read a letter of informed consent and obtained the participants' verbal consent to participate in this study.

For inclusion in the current study, participants had to (i) have been involved in agroindustry for more than 10 years and have been responsible for leading or managing a production-oriented agribusiness; (ii) have received central or local government recognition (e.g., the One Town One Product Award or Agribusiness Science \& Technology Innovation Award); (iii) be a renowned expert in the Taiwanese agroindustry; and (iv) be willing to be interviewed. These criteria allowed for a certain degree of diversity in the participants, such as different fields of agriculture (e.g., crop, fertiliser, tea, fruit, and beekeeping). Therefore, a broad range of expert managers' experiences could be explored. The ages of the participants ranged from 35 to 78 years. The participants were coded as M1 to M10.

\section{Data collection}

Semi-structured in-depth interviews were conducted from 5 May 2015 to 10 June 2015 as a flexible and responsive approach to determine the recent managerial practices of the study participants. The interviews, which lasted for approximately 120-150 minutes, were audio-recorded and transcribed after receiving permission from the participants. The process was identical for all interviews to ensure uniform quality. The following prompts derived from the literature review were included in the topic guide to elicit the 
experiences and opinions of each participant: 'What external environment factors influence the operation of your agribusiness?' and 'How do you handle these factors in terms of strategic management?' We then asked additional questions regarding the external environment and inquired about the other two dimensions, namely the internal environment and sustainable development. Table 1 lists the questions for each dimension of strategic management.

Table 1. Interview questions for the three dimensions of strategic management

\begin{tabular}{|c|c|}
\hline Dimension & Interview Questions \\
\hline \multirow[t]{4}{*}{$\begin{array}{l}\text { External } \\
\text { environment }\end{array}$} & $\begin{array}{l}\text { What is the future development of agroindustry? What opportunities will } \\
\text { appear for Taiwanese agroindustry? }\end{array}$ \\
\hline & $\begin{array}{l}\text { Who are the competitors your agribusiness faces? How do you confront } \\
\text { this competition? How do you enhance the competitive advantages of your } \\
\text { agribusiness? }\end{array}$ \\
\hline & $\begin{array}{l}\text { What are your cooperative strategies for dealing with your suppliers? How } \\
\text { do you ensure supply quality and efficiency? }\end{array}$ \\
\hline & $\begin{array}{l}\text { What are the distribution channels you cooperate with? How do you ensure } \\
\text { distribution stability? }\end{array}$ \\
\hline \multirow[t]{3}{*}{$\begin{array}{l}\text { Internal } \\
\text { environment }\end{array}$} & $\begin{array}{l}\text { What are the goals and direction of your agribusiness? What are your plans } \\
\text { for different product lines? Do you have any thoughts about new product } \\
\text { development? }\end{array}$ \\
\hline & $\begin{array}{l}\text { What are your marketing plans and approaches? Do you have any innovative } \\
\text { marketing strategies for the future? }\end{array}$ \\
\hline & $\begin{array}{l}\text { What are your organisational structure, human resource, and financial } \\
\text { management plans for facilitating future development? }\end{array}$ \\
\hline $\begin{array}{l}\text { Sustainable } \\
\text { development }\end{array}$ & $\begin{array}{l}\text { What social responsibilities should an agribusiness carry? Do you have any } \\
\text { ongoing practices and future plans for ecological sustainability and social } \\
\text { responsibilities based on satisfactory economic performance? }\end{array}$ \\
\hline
\end{tabular}

\section{Data analysis}

The three authors of this study coded the interview transcripts independently to avoid influencing each other. A 'theory-driven' strategy based on the literature review was used as the initial coding framework, which allowed new themes to emerge from the data analysis process (Braun \& Clarke, 2006). The interview transcripts were thus indexed and mapped according to the three dimensions (external environment, internal environment, and sustainable development). The synthesised data were examined to identify explanatory accounts that emerged in the process.

To ensure the quality of this study, triangulation was performed, resulting in the following measures for reliability and validity: (i) a topic guide was used to ensure that a similar range of topics was discussed with each participant; (ii) each interview transcript was sent to the participant for revision and confirmation; (iii) the coding process was performed by all three researchers; 
and (iv) the researchers compared the transcript contents with the reviewed literature to determine whether any topics required further discussion.

The inter-rater reliability of each theme was independently calculated by two raters (the first and corresponding authors), which prevented the raters from influencing each other. Cohen's kappa statistical test was used to measure intercoder reliability and revealed significant consistency in the scores assigned by an expert in agribusiness management (the second author). The Cohen's kappa of this study was 0.86 (>0.70), indicating a significant correlation $(p<0.01$ ) between the results of each rater (Banerjee, Capozzoli, McSweeney, \& Sinha, 1999).

\section{RESULTS}

\section{External environment}

Three themes related to the external environment emerged during the analysis process, namely agricultural development trends, agroindustry competition analysis, and social networks. Each subtheme is discussed as follows.

\section{Agricultural development trends}

The participants perceived the agroindustrial environment to be an essential aspect of agribusiness strategy, making comments such as 'We previously focused only on planting, but now consumers are increasingly concerned about the quality and safety of our products' (M3), and 'We invested in agriculture, and have specialised in home-grown nontoxic organic fruits and vegetables for our own supermarkets. After withstanding 3 years of losses, we finally broke even this year' (M10). This result agreed with those of previous studies (e.g., Kennedy et al., 1998), indicating that closely monitoring the dynamics of the consumption market and responding to them appropriately are essential strategies in modern agribusiness.

The participants indicated that international trading was also a critical aspect of agribusiness strategy, stating that 'the Japanese government sends experts to the countries that import its products to learn their pricing policy and market channels. These experts then analyse and provide business information to Japanese farmers. High-quality Taiwanese fruits are considered satisfactory by Japanese and Singaporean customers' (M4). Another participant said, 'Customer selection of imported products largely depends on national image' (M8). This result agreed with those of previous studies (e.g., Karelakis et al., 2008) indicating that a customer-oriented (rather than 
product-oriented) approach should be considered in international agricultural trading to establish a market position and develop product features.

The participants noted the dual effects of government policy, namely creating advantages and causing problems, as indicated in the literature. For example, participants stated that 'Taiwanese farmers have abundant opportunities, but numerous innovative actions are restricted by government regulations' (M2), and that 'The government should determine Taiwan's position and strategic values in the global market, and then make policies to guide domestic farmers' (M4). This result agreed with prior research (Hartwich \& Negro, 2010; Rosairo et al., 2012), which suggests that the government should have a clear plan to support innovation through various funding schemes, and simultaneously foster agribusiness collaboration.

Risk assessment was another crucial aspect of agribusiness strategy noted by the participants, in comment such as 'Today's agribusinesses must be capable of performing risk assessment. Even in the case of a climate problem, there must be a stop-loss point' (M6), and 'I have invested in several product certifications, but there are certainly unforeseeable risks ahead that I need to prepare alternatives for' (M9). This result agreed with those of earlier studies (e.g., Russo et al., 2003) indicating that a cautious assessment regarding the risks of R\&D investment is a crucial strategy for agribusinesses facing environmental uncertainties.

\section{Agroindustry competition analysis}

The participants indicated that identifying the core competence of an agribusiness was the most effective strategy for enhancing competition, stating, for example: 'The core competence may depend on the market and competitors rather than ourselves. To me, ensuring product quality is the best core competence' (M7), and 'We have adopted an ERP [enterprise resource planning] system to stabilise our planned production, which is irreplaceable' (M9), and 'Our ecological farming and quality monitoring systems, which gained us ISO 2200, HACCP [Hazard Analysis Critical Control Point], and ASC [Aquaculture Stewardship Council] certificates, are a powerful weapon for outperforming competitors' (M10). This result concurred with those of prior research (Dobson, 1992; Giannakas \& Tzouvelekas, 1998), indicating that unique agribusiness management and technology have become increasingly crucial as agroindustry has become more competitive.

The development of competitor counterstrategies was also frequently mentioned by the participants. For example, participants stated: 'Product quality must be good, or we will not be able to sell our products in highend distributors like Costco. Compared with competitors, our product quality 
is certificated' (M9). This result concurred with those of previous studies (e.g., Russo et al., 2003), which have suggested that product differentiation and quality certification are appropriate strategies for gaining competitive advantages in agroindustry.

Another relevant strategy noted during the interviews was competing with potential entrants, with participants stating, for example, 'Our strategy is mass production to block competitors and potential entrants' (M1), 'Only by establishing a unique brand emphasising the differentiation of product quality can we win price wars initiated by potential entrants' (M4), and 'Agriculture itself has a certain professional threshold. Partners in a vertical alliance have greater chances of becoming competitors' (M6). This result concurred with those of prior research (Russo et al., 2003; Westgren et al., 1988 ) in indicating that promoting production efficiency, reducing costs, and enlarging the economic scale are feasible competitive strategies.

\section{Social networks}

Agricultural production, processes, and distribution involve specific professions and complex networks, among which the supply chain is crucial, according to the participants. For example, participants said: 'We adopt information technology intensively. From planting to harvesting, we have a strong alliance with automatic control vendors' (M8), 'Having a stable supply and maintaining a certain quality are crucial for the domestic small-scale agricultural system' (M9), and 'I have travelled around Taiwan and developed a comprehensive farming map. I know what, where, and how to purchase what I need' (M10). This result echoed those of previous studies (e.g., Amanor-Boadu et al., 2009), which have indicated that Taiwanese agricultural workers, particularly technology vendors and expert farmers, must consider supply chains as a strategic resource.

Because the agribusinesses owned by the participants in this study were production-oriented, distribution channel was frequently mentioned while discussing social networks; for example, participants said: 'The major distributors we cooperated with were renowned supermarkets including Costco. Soon, after the Internet of Things has matured, our products may be sent to consumers directly' (M1), 'Selling has been a big obstacle to small or traditional agricultural workers. The price is controlled by distributors who may not spend time promoting the product value' (M3), 'Modern farmers must understand marketing to deal with various distributors' (M4), and ' $20 \%$ of our products are sold in farmers' markets, $30 \%$ by distributors, and the rest in our own store' (M6). This result, like those of previous studies (Bhuyan, 2005; De Moura et al., 2009), indicated that marketing has become 
an essential skill for modern farmers, helping them promote product value, manage interactions with distributors, and increase revenue.

In addition to noting supply chains and distribution channels, the participants emphasised the critical role of strategic alliances in agribusiness strategy, stating, for example: 'Taiwanese agriculture benefits through strategic alliances, which create brand names, expand market size, provide consultation, and sell agriproducts or package plant exports' (M2), 'We need innovative thinking to lead young farmers and their partners to create a new business model through strategic alliances' (M3), and 'I am good at information flow and resource integration, enabling me to think from both the production and consumption side. I am thus able to identify and develop different alliances to break into the market' (M4). This result echoed those of previous studies (e.g., Gall \& Schroder, 2006), indicating that both horizontal and vertical strategic alliances among the actors involved in production, processing, and distribution are crucial to small-scale Taiwanese agribusiness.

A total of 4 of the 10 participants were involved in family businesses; hence, family interaction was commonly suggested as a critical aspect of strategic management. For example, participants stated: 'Family support is particularly important during the period of early operation. In addition, the interaction between generations is critical during business transition, which is time-consuming and often rife with conflict' (M3), 'My father did not know how essential brand management, multiple channels, and new product development are. Communication with him was difficult, even, I would say, useless' (M5), 'This is a third-generation tea business. My father criticised my efforts at branding as nonsense until I turned a profit' (M7), and 'My dad thought that I was crazy when I prepared to apply for certification. The certification requires a few million [Taiwanese] dollars to maintain per year and involves evaluation by foreigners. He became silent after our products were allowed to be sold in Costco and even exported abroad' M9). This result, which is supported by prior research (Heiman et al., 2001), indicated that continual communication and accumulated achievements are a common agribusiness strategy for managing family dynamics or generational conflicts.

\section{Internal environment}

Four themes related to the internal environment emerged during the analysis process, namely goal setting, production management, marketing management, and business administration. 


\section{Goal setting}

Compared with traditional farmers, new-generation farmers, particularly agrientrepreneurs, stressed business philosophy more when discussing their managerial practices. For example, participants stated: 'I plan to use part of my land for organic farming. It will create value for me' (M3), 'After all these years, I decided to come back to Taiwan to participate in land reform and help improve domestic agroindustry' (M4), 'I have spent most of my life in high-tech business and decided to engage in a career closer to the land and people' (M6), and 'By using specific baking techniques, I divide tea products into 10 categories, which enables customers to enjoy different tastes' (M7). This result agreed with those of earlier studies (e.g., Baker \& Leidecker, 2001), indicating that the dual goals of environmental protection and value creation were common among the participants.

The participants also stressed the importance of vision development for agribusiness, saying 'We wish to cultivate 40 young generations of organic farmers, and for each of them to transfer their techniques and experiences to 40 farms. Our agricultural dream is to facilitate Taiwan becoming an organic nation' (M8), and 'We are the first cooperative in Taiwan with certified product traceability. We have developed an operation process specific to a smallscale farming system based on the core technology of a large-scale system' (M10). This result concurred with those of previous studies (e.g., Leidecker, 2001), indicating that the participants sought traceability certification and technique transfer to support their missions and achieve their goals.

Business transformation is another crucial strategy cited by the participants, who said, for example: 'A capable entrepreneur should be able to handle both red ocean and blue ocean markets. The red ocean market is certain and large-the main battlefield. The blue ocean market may currently be a niche but is also a future red ocean' (M1), 'In addition to selling fertiliser, we have engaged in the manufacture of fertiliser-making equipment, and then sold the equipment, techniques, and even the materials. Some of our equipment is patented' (M2), and 'We are continually expanding and learning by doing, and are gradually being accepted by consumers' (M3). This result agreed with those of prior research (e.g., Westgrem et al. (1988), indicating that product-oriented entrepreneurs are sensitive to changes in the market and capable of restructuring their agribusinesses accordingly.

The participants frequently mentioned the inevitable internationalisation of Taiwanese agribusiness because of the participation of the Taiwan government in the World Trade Organisation. For example, 'I do not think pricing competition is a good idea for a small-scale farming system. By securing the quality of our agriproducts and shaping Taiwan as a high-standard living environment, Taiwan will gain a prestigious image and its products will be 
accepted by advanced customers' (M4), 'Taiwanese agriculture has plenty of professional techniques and managerial knowledge that can be packaged as consultation services' (M8), and 'I expended enormous effort to apply for certifications such as ASC and ISO to cross over the trade barrier to various international markets' (M9). This result echoed those of earlier studies (e.g., Kennedy et al., 1998), indicating that product quality and agricultural knowledge are feasible internationalisation strategies for Taiwanese agribusiness. In addition, this result suggested that the government should exert more effort in elevating Taiwan's image abroad.

\section{Production management}

The participants perceived product quality as the most crucial requirement in agribusiness, saying, for example: 'Consumers will not return if product quality does not meet their expectations. Agriproducts cannot just rely on gimmicks or advertisements; if they do, they will not survive long' (M1), and 'The chickens I breed are higher-quality than those of my competitors in terms of both appearance and taste. It is an unbeatable strategy' (M6). This result concurred with those of earlier studies (Capitanio et al., 2010; LülfsBaden et al., 2008), indicating that maintaining high product quality is one of the most effective strategies for creating differentiated value.

The participants stressed that instead of relying on the weather, optimising operation management to secure product quality and profit was critical for Taiwanese agribusinesses. Participants said, for example: 'We can analyse the accumulated data of our automated systems to establish longterm temperature- and humidity-monitoring and feedback mechanisms' (M1), 'We have done well in materials management, which in turn has generated profits' (M2), 'From planting to harvesting, automated production systems help us reduce manpower and costs, improve production efficiency and product quality, and break through environmental limitations to achieve planned production' (M8), and 'We record every detail of the production process in the computer system. Even quality investigators from Japan are persuaded by our records' (M10). This result echoed those of previous studies (e.g., Boehlje et al., 2011), indicating that enhancing operation management through ICT systems aids Taiwanese agribusinesses in satisfying customers, confronting competition, and generating profits.

Although Taiwanese agribusinesses are small in scale, the participants suggested that $R \& D$ investments for innovation were necessary. For example, 'We found that the biodegradation of earthworm stools makes soil fertile. In other words, earthworms can be both feed and fertiliser and thereby generate derivative products' (M2), 'I often observe competitors' business models. 
If they are the same as mine, I will make mine different' (M3), 'The initial pineapple cake mix is combined with butter, milk, eggs, and fragrance oil. I use tea to moderate the smell and differentiate the product' (M5), and 'We imported new breeds of vegetables from Japan and modified the traditional planting method. We started to make a profit and were even able to sell the product back to Japan after 5 years of losses' (M10). This result echoed those of previous studies (Gellynck et al., 2015; Liu et al., 2014), indicating that investment in product or process innovation can enhance product attractiveness, reduce production costs, and increase market potential.

\section{Marketing management}

Marketing has long been a weakness of Taiwanese agribusinesses, but new generations of agrientrepreneurs are focusing on the development of diverse marketing strategies to increase revenue. For example, participants stated: 'Although attractive packaging cannot hide rotten apples, I must admit that branding and package design in the agrifood market have improved greatly in the past 10 years in Taiwan' (M1), 'Taiwanese agrifood product development must have value-added concepts. Agribusiness must understand and embed customer-perceived values, such as place attachment and environmental friendliness, into product design' (M3), and 'Faced with an ever-changing market, product diversity and even product demand can be effective marketing strategies' (M5). This result concurred with those of earlier research (Micheels \& Gow, 2008), indicating that to promote consumer perceptions of product quality and superiority, marketing strategies can focus on consumer needs, product differentiation, local attributes, and environmental friendliness.

In addition to noting marketing strategies, the participants emphasised the importance of branding on the basis of market positioning and product values. For example, participants stated: 'We have a brand under which we offer low-cost products. "Low cost" is a type of branding strategy that does not mean low quality' (M1), 'A brand can represent a company's image, providing a quality guarantee to its consumers' (M5), and 'I have tried to establish a standard tea taste, which is my branding strategy, and then I can position my products at specific consumption levels' (M7). This result echoed prior research (e.g., Hanf \& Kühl, 2005), indicating that agribusiness branding is a shaping process based on product quality and market niche that must be continually invested in and carefully maintained.

Customer service was another crucial marketing management aspect indicated by the participants, who said, for example: 'Involving customers in the design and manufacturing process is also a type of customer service, allowing them to input feedback and see our commitment to product quality' 
(M5), 'Some of my FB [Facebook] fans look at my farm pictures and doubt whether they are real. I then invite them to visit the site. They love the farm trips I arrange' (M6), and 'I strive for the youth market by using advanced high-pressure extraction and ice droplet techniques to provide pre-packaged cold drinks to young customers' (M7). This result concurred with those of earlier studies (Boehlje et al., 2005; Lülfs-Baden et al., 2008), indicating that designing participative experiences and satisfying consumption preference are feasible strategies for increasing realistic interaction and emotional links with customers, which in turn promote customer satisfaction and loyalty.

The participants also cited social media as a strategic practice in marketing management. For example, participants said: 'Participating in exhibitions is a basic activity for brand expansion, but usually does not yield many orders. I believe social media offers opportunities in e-commerce' (M3), 'I am searching for opportunities to cooperate with some cultural and creative shops, and with social media' (M4), and 'We used social media to set up a network of markets, stressing "same-day harvesting and shipping and nextday arrival". We began a membership program, which incorporated bonus point's accumulation to establish customer loyalty. We need professionals to run this platform' (M8). This result concurred with those of earlier studies (Henderson et al., 2005; House et al., 2008), indicating that effectively exploiting social media is a necessary strategy for reaching out to potential customers, establishing customer relationships, and building customer loyalty.

\section{Business administration}

The participants indicated that financial management was critical for agribusiness success, saying, for example: 'Traditional family businesses tend to be concerned with revenue, but I care about financial planning and innovation investments' (M6), 'I am considering establishing a holding company to introduce funds from capital markets' (M8), and 'I am not sure whether I want to introduce venture capital into my company at this time' (M9). This result concurred with those of earlier studies (Boehlje et al., 2011; Westgren et al., 1988), indicating that in addition to ensuring profits, the financial management of modern agribusiness should include raising and allocating capital for both short-term and long-term objectives.

Employee development was also frequently noted by the participants, who said, for example: 'Through the application of automated systems, chicken breeding has become a business that does not entirely rely on experience. I hope this change will attract more young people to the industry, and we can assist them through remote-monitoring techniques' (M1), 'The 
business of waste recycling requires professional certification. We provide our employees with the necessary training and help them apply for certificates. Soon after they are certified, we raise their salaries. Our employees have more certificates than our competitors do' (M2), and 'In traditional family businesses, employee relationships do not really require specific care. New generations of agribusinesses must pay attention to employee development to attract talented partners' (M10). This result agreed with those of previous studies (e.g., Baker et al., 1994), indicating that reducing workload by using IT technology, offering more professional knowledge and skills, and increasing incomes and ownership are viable strategies for attracting and maintaining employees in rural agribusiness.

\section{Sustainable development}

Three themes related to sustainable development emerged during the analysis process, namely ecological protection, social responsibility, and economic development.

\section{Ecological protection}

The participants indicated that ecological protection was the first step to sustainable development. For example, participants said: 'If we do not handle poultry droppings, who will do it? Industrial manufacturers use these as fuel, which causes air pollution. Some partners and employees question why I invest equipment to process this litter. "It is a waste of money", they said. ... Waste processing must comply with regulations. We cannot hurt our land' (M2), "If the farmer does not take care of the land, the land will not produce any healthy goods. "Organic" means "back to nature"' (M3), 'I was an engineer in the semiconductor industry, and witnessed wastewater pollution every day. I felt bad and decided to quit, turning to organic farming. If the land is destroyed, it will not return to how it once was. I keep telling my friends this' (M6), and 'I encourage farmers to return to traditional agricultural practices. This not only generates quality crops but is also good for the land' (M7). This result agreed with those of earlier studies (Hansford et al., 2003; Thompson, 2007), indicating that insistence on ecological protection and organic practices is the most effective mechanism for sustainable development.

\section{Social responsibility}

In addition to emphasising ecological protection, the participants stressed the broader concept of social responsibility, saying, for example: 'Organic farming 
is not an easy task, but we are more than happy to share our experience. I feel that it is our responsibility' (M2), 'If our experiments in farming practices and online commerce succeed, I will share these experiences in detail, which will benefit society as a whole' (M3), 'The key difference is the people. Domestic agriculture needs to be reformed. The whole system needs to be changed' (M4), 'Agribusinesses should help farmers sell products and make a reasonable profit. We help producers do some processing and packaging, which generates profits, and we enable consumers to eat safe and healthy food. This is our responsibility-to make everyone happy' (M5), and 'We have a responsibility to share. When I make a profit, I donate some of it to charity' (M6). This result concurred with those of earlier studies (Horrigan et al., 2002; Lubell et al., 2011), indicating that knowledge transfer, the sharing of experiences, environmental friendliness, humanitarian assistance, and social care are perceived as the social responsibilities of modern agribusinesses.

\section{Economic development}

The participants all agreed that agribusiness is distinct from philanthropy and that making a reasonable profit and facilitating economic development are crucial for sustainable development. For example, participants said: 'I hope that every Taiwanese agribusiness will become a social enterprise with dual goals of economic development and social impact. For instance, taking $30 \%$ of your profits and investing it back in the land and the people facilitates a greater scale of sustainable development' (M4), 'It is critical to develop agricultural companies into creative businesses. Quality products with exceptional packaging guarantee a market' (M5), and 'We are building a cultivation platform for the transfer of agricultural knowledge. We wish to quickly cultivate hundreds of young farmers to act as seeds in each rural town in Taiwan. We promise them that we will purchase $100 \%$ of their harvests' (M10). This result agreed with those of earlier studies (Häni et al., 2007; Lubell et al., 2011), indicating that the development of agrisocial enterprises, the business models of these enterprises, and lessons learned from creative industry can be critical guides to economic development for Taiwanese agribusiness.

\section{DISCUSSION}

According to the results, the strategic management of Taiwanese agribusiness can be planned and assessed using three dimensions: the external environment, the internal environment, and sustainable development (see Figure 1). Each dimension has subthemes, which are discussed as follows. 


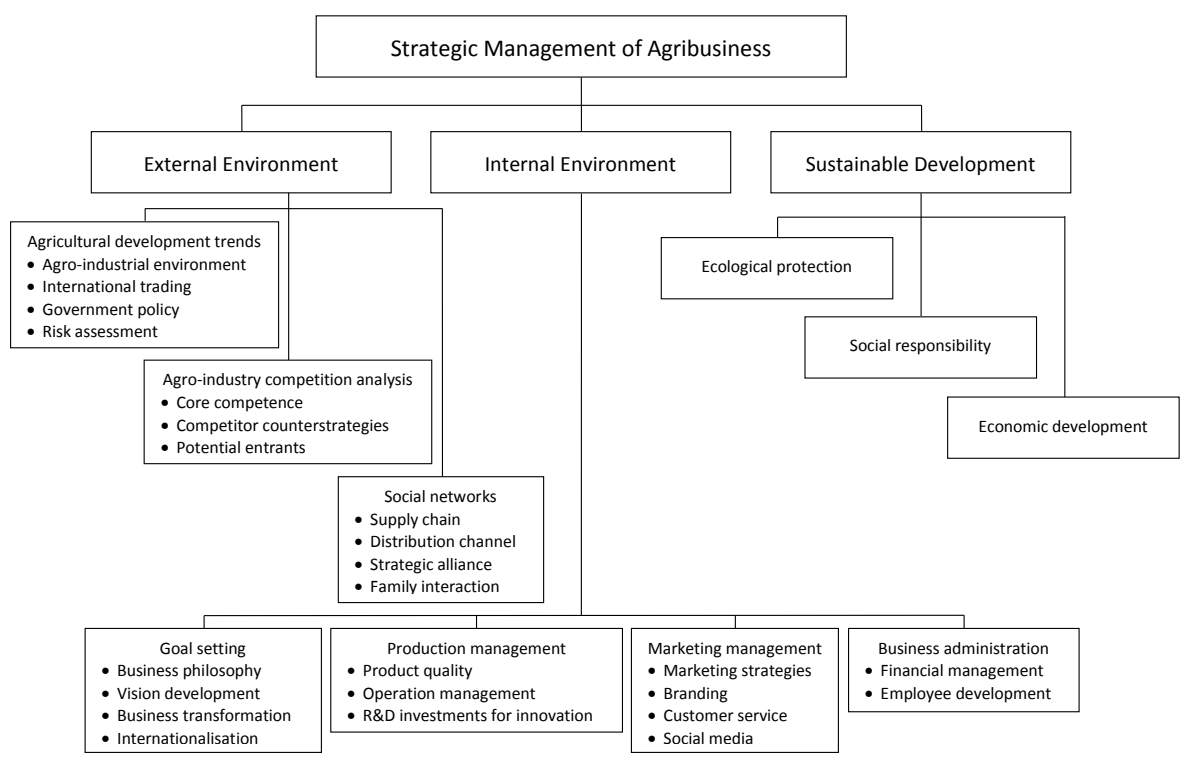

Figure 1. Strategic management of Taiwanese agribusiness

\section{External environment}

Although most of the aforementioned agribusiness strategies related to the external environment align with those reported in previous research, the results of our study revealed several noteworthy topics that warrant future inquiry. First, the participants in this study seldom mentioned export competence or product adaptation, which were proposed by Karelakis et al. (2008) as key strategies. This may have been because production-oriented agribusinesses may not require export competence and because foreign customers may prefer natural rather than adaptive agricultural products. Future research should examine food processing- and commodity-oriented agribusinesses to determine whether demand differs according to export competence and product adaptation.

Second, although prior research indicated that government initiatives do not foster collaboration (Hartwich \& Negro, 2010), the participants in this study seldom complained about this; rather, they stressed the need to assess R\&D risks. This result can be explained by the fact that the Taiwanese government usually subsidises individual agribusinesses rather than encouraging collaboration among businesses. Because of Taiwan's small-scale agricultural system, most agricultural companies tend to be highly cautious about R\&D investments. This explains why the participants emphasised the importance of risk assessment. 
Third, building on earlier studies (e.g., Dobson, 1992; Russo et al., 2003), the current study contributed to the understanding that management and technology have become the core competence of Taiwanese agribusiness. The strategies of product differentiation, production efficiency, quality certification, cost reduction, and increasing economic scale particularly benefit competitive advantages in the Taiwanese agroindustry. The aforementioned strategies seem more feasible for a small-scale agriculture system than product innovation does.

Fourth, the recent literature on agribusiness strategy (e.g., Bhuyan, 2005; De Moura et al., 2009) has stressed that social networks are a strategic resource. The results of this study demonstrated that specific types of supply chains (i.e., technology vendors and knowledgeable experts) and strategic alliances (both horizontal and vertical) benefit Taiwanese agribusiness. The results also indicated that marketing is essential knowledge for contemporary farmers, and that accumulated achievements can resolve generational conflicts. However, these results did not illuminate the possible role of farming cooperatives, nor highlight the potential of NGOs or social enterprises in social networks; thus, these topics warrant further research.

\section{Internal environment}

As with the findings related to the external environment, most of the findings on strategies related to the internal environment concurred with those of previous studies; however, we observed some notable results reflecting the specific context of Taiwanese agribusiness. First, this study elucidated the transformation of goal setting from profit orientation to environmental friendliness and value creation, indicating that the business philosophy of modern agrientrepreneurs differs greatly from that of older generations. Whether this also reflects these entrepreneurs' flexible marketing strategies and diverse income channels merits further research.

Second, the participants all emphasised the importance of enhancing operation management through ICT systems and creative investments. Taiwan has long been a world leader in ICT hardware manufacturing. Taiwanbased firms account for more than $90 \%$ of global notebook and tablet production (Yee, 2014). This industrial development has profoundly affected the decisions and practices of Taiwanese agribusinesses. In addition, the small scale of Taiwanese agriculture limits agrientrepreneurs' financial planning abilities. However, the current results revealed that young generations of Taiwanese agribusiness workers are making creative and flexible investments for innovations in both agricultural products and processes. 
Third, to these agrientrepreneurs, product differentiation, local attributes, branding maintenance, designing participative experiences, and environmental friendliness were essential marketing strategies. Although prior research (e.g., Hanf \& Kühl, 2005) has demonstrated the crucial role of vertical coordination in marketing plans, the participants in this study did not emphasise this role. This was possibly because these production-oriented participants did not thoroughly engage in the marketing planning process. Furthermore, the participants did not articulate how to achieve a balance between product quality and marketing planning for consumers. These results indicate the need for further investigation.

Fourth, regarding business administration, the participants stressed the importance of human resources and financial capital. Raising and allocating capital requires entrepreneurs to possess financial knowledge, management experience, and organisational vision, which are generally insufficient in small-scale agribusinesses. In addition, from 1992 to 2012, the agricultural population declined from 1 million to 640,000 (Agricultural Statistics Yearbook, 2013). As of 2015, the average age of farmers was 63 years, highlighting the serious lack of young people entering agriculture in rural Taiwan. Therefore, reducing workloads, adding values, and increasing the incomes and ownership of agriculture businesses have become strategies to attract young generations to engage in rural agricultural work. These difficult realities reflect the need for future theoretical and practical research.

\section{Sustainable development}

The concept of sustainable development has spread across the world. Taiwan is no exception. First, although the participants in this study strongly emphasised the importance of ecological protection and organic practices, they did not include agricultural multi-functionality, one of the most critical aspects of modern agriculture. In addition, sustainable development can be assessed using various indicators (e.g., Häni, Stämpfli et al., 2007; Zahm et al., 2007), only some of which were mentioned by the participants. These deficiencies probably stem from the participants being productionoriented entrepreneurs, resulting in incomplete perspectives. Furthermore, the development of agrisocial enterprises, the business models of these enterprises, and lessons learned from the creative industry as detailed by the participants seem promising for agribusinesses, both domestically and globally. These topics could also be future directions for agribusiness research. 


\section{RESEARCH LIMITATIONS}

The results of this study offer potential contributions to research on the strategic management of Taiwanese agribusiness, but several study limitations should be acknowledged. First, the current study was limited to production-oriented agrientrepreneurs. Future research could replicate this study design and focus on participants with other orientations (i.e., processing or commodities) to explore a broader range of strategic management. Second, we interviewed 10 renowned agrientrepreneurs, and data saturation was achieved (i.e., no new themes emerged) after eight interviews were conducted. However, several critical topics, such as agricultural multi-functionality and social enterprise, were not covered in the present study and require further exploration. Third, agricultural problems are increasingly solved by teams; however, we did not collect data from the participants' team members. Consequently, any potential influences of teamwork on agribusiness management were not examined, and these factors should therefore be considered in future research.

Fourth, comparing the strategic management of expert agrientrepreneurs with that of naïve entrepreneurs might be an insightful research direction. Identifying the differences between these two groups might yield valuable information regarding entrepreneurial education in the agricultural field. Fifth, the strategies of agrientrepreneurs cannot be realised without feedback from alliance partners and responses from competitors; however, we did not consider these in our study. How effective these strategies would be is a topic warranting further study. Sixth, the research method adopted in the present study involved semi-structured in-depth interviews. The method, design, and process adopted in this study could be transformed into a series of case studies to obtain a wider range of insights. Finally, the participants were Taiwanese agrientrepreneurs who had been identified through the authors' personal relationships and invited to participate in the study. Future research could extend participation on a global scale to examine the possible impact of sociocultural contexts.

\section{CONCLUSION}

Despite the limitations of this study, we believe that our research provides insights into the complexities of agribusiness management, from which some notable conclusions can be drawn and summarised as follows. First, the strategic management of agribusiness, particularly in a Taiwanese context, can be organised and evaluated in three dimensions: the external environment, the internal environment, and sustainable development. Figure 1 provides such a strategic framework for future directions for both 
theoretical and applied studies regarding agrientrepreneurship, the strategic management of agribusiness, and agricultural education. Second, new generations of agrientrepreneurs closely monitor the dynamics of domestic and international markets and respond accordingly, and view product differentiation, quality certification, production efficiency, cost reduction, branding, and economic scale as strengthening their competitiveness. Third, the social networks these entrepreneurs handle differ in diversity. For example, they perceive technology vendors and expert farmers as their critical supply chains. In addition, marketing knowledge has become a necessity for performing horizontal and vertical coordination.

Forth, newer generations of agrientrepreneurs typically have clearer goals and a stronger business philosophy than older generations do. They know that quality products and agricultural knowledge are weapons for internationalisation, and these entrepreneurs are capable of restructuring their agribusinesses to fit the changing world market. Fifth, these agrientrepreneurs use ICT systems and flexibility to invest in product and process innovations that improve operation management and enhance production efficiency, which in turn promotes product quality. Sixth, the marketing strategies of these entrepreneurs focus on consumer needs, product differentiation, local attributes, environmental friendliness, participative experience, social media, and continual branding investments. Seventh, entrepreneurs exert great effort in financial management and human resources management to attract diverse capital into rural agricultural areas. Finally, belief in organic practices, knowledge transfer, the sharing of experiences, environmental friendliness, humanitarian assistance, and social care enables agrientrepreneurs to outperform their competitors. The possibility of transformation into an agrisocial or creative enterprise facilitates the achievement of the AgriGold dream.

Examining these conclusions reveals five broader trends of strategic management: (1) innovative technology must be continually developed and adopted to secure long-range success; (2) corporate decisions must be made on the basis of social responsibility and business ethics in an environment of increasing uncertainty; (3) the values of ecological friendliness must be strengthened and delivered to alter the conditions and methods of competition; (4) the practices of sustainable development must be modified in response to changes in industry structure and boundaries; and (5) each organisation must be viewed as a unique collection of resources and relationships to be developed and innovated. 


\section{References}

Agricultural Statistics Yearbook (2013).Taipei: Council of Agriculture, Executive Yuan.

Amanor-Boadu, V. R., Marletta, P., \& Biere, A. (2009). Entrepreneurial supply chains and strategic collaboration: The case of Bagòss Cheese in Bagolino, Italy. International Food and Agribusiness Management Review, 12(3), 49-68.

Baker, G. A., \& Leidecker, J. K. (2001). Does it pay to plan? Strategic planning and financial performance. Agribusiness, 17(3), 355-364.

Baker, G. A., Starbird, S. A., \& Harling, K. F. (1994). Critical success factors for managing quality in food processing firms. Agribusiness, 10(6), 471-480.

Banerjee, M., Capozzoli, M., McSweeney, L., \& Sinha, D. (1999). Beyond kappa: A review of interrater agreement measures. Canadian Journal of Statistics, 27(1), 3-23.

Bhuyan, S. (2005). An empirical evaluation of factors determining vertical integration in U.S. food manufacturing industries. Agribusiness, 21(3), 429-445.

Boehlje, M., Doehring, T., \& Sonka, S. (2005). Farmers of the future: Market segmentation and buying behavior. International Food and Agribusiness Management Review, 8(3), 52-68

Boehlje, M., Roucan-Kane, M., \& Bröring, S. (2011). Future agribusiness challenges: Strategic uncertainty, innovation and structural change. International Food and Agribusiness Management Review, 14(5), 53-82.

Bond, C. A., Thilmany, D., \& Keeling Bond, J. (2008). Understanding consumer interest in product and process-based attributes for fresh produce. Agribusiness, 24(2), 231-252.

Braun, V., \& Clarke, V. (2006). Using thematic analysis in psychology. Qualitative Research in Psychology, 3(2), 77-101.

Capitanio, F., Coppola, A., \& Pascucci, S. (2010). Product and process innovation in the Italian food industry. Agribusiness, 26(4), 503-518.

Cohen, D., \& Crabtree, B. (2006). Qualitative research guidelines project. Retrieved March 1, 2016, from http://www.qualres.org/HomeSemi-3629. html.

de Moura, A. D., Martin, S., \& Mollenkopf, D. (2009). Product specification and agribusiness chain coordination: introducing the coordination differential concept. Agribusiness, 25(1), 112-127.

Dess, G. G., Lumpkin, G. T., \& Taylor, M. L. (2005). Strategic management: Creating competitive advantages (2 Ed.). New York, NY: McGraw-Hill Irwin.

Dobson, W. D. (1992). Competitive strategies of US fluid milk processors: A case study. Agribusiness, 8(5), 425-444.

Financial Times (2015). Wanted: Flexible corporate strategies for fast times. 26 March, p. 8. 
Gall, R. G., \& Schroder, B. (2006). Agricultural producer cooperatives as strategic alliances. International Food and Agribusiness Management Review, 9(4), 26-44.

Ghemawat, P. (2002). Competition and business strategy in historical perspective. Business History Review, 6(1), 37-74.

Gellynck, X., Cárdenas, J., Pieniak, Z., \& Verbeke, W. (2015). Association between innovative entrepreneurial orientation, absorptive capacity, \& farm business performance. Agribusiness, 31(1), 91-106.

Giannakas, K., \& Tzouvelekas, V. (1998). Strategic behavior and competition in dynamic industry: Greek processed meats. Agribusiness, 14(2), 157-169.

Goldsmith, P., \& Gow, H. (2005). Strategic positioning under agricultural structural change: A critique of long jump cooperative ventures. International Food and Agribusiness Management Review, 8(2), 41-61.

Hanf, J. H., \& Kühl, R. (2005). Branding and its consequences for German agribusiness. Agribusiness, 21(2), 177-189.

Häni, F. J., Pintér, L., \& Herren, H. R. (2007). Editors' preface. In the proceedings and outputs of the first Symposium of the International Forum on Assessing Sustainability in Agriculture (INFASA, pp. vii-viii), March 16, 2006, Bern, Switzerland.

Häni, F. J., Stämpfli, A., Gerber, T., Porsche, H., Thalmann, C., \& Studer, C. (2007). RISE: A tool for improving sustainability in agriculture. In the proceedings and outputs of the first Symposium of the International Forum on Assessing Sustainability in Agriculture (INFASA, pp. 121-148), March 16, 2006, Bern, Switzerland.

Hansford, P., Cary, J., \& Coath, E. (2003). Sustainable agribusiness: Developing local solutions to global challenges in the regional agribusiness sector in Australia. International Food and Agribusiness Management Review, 5(4), 1-10.

Harling, K. F. (1988). Strategic management of farm supply and grain elevator businesses. Agribusiness, 4(4), 301-314.

Harling, K. F. (1994). Business strategies as a market opens: A case study of Ontario wineries. Agribusiness, 10(3), 259-273.

Hartwich, F., \& Negro, C. (2010). The role of collaborative partnerships in industry innovation: lessons from New Zealand's dairy sector. Agribusiness, 26(3), 425-449.

Heiman, A., Just, D. R., McWilliams, B., \& Zilberman, D. (2001). Incorporating family interactions and socioeconomic variables into family production functions: The case of demand for meats. Agribusiness, 17(4), 455-468.

Henderson, J., Dooley, F., Akridge, J., \& Carerre, A. (2005). Adoption of internet strategies by agribusiness firms. International Food and Agribusiness Management Review, 8(4), 42-61.

Higgins, J. M. \& Vincze, J. W. (1993). Strategic management: Text and cases. Fort Worth, PA: Dryden Press. 
Horrigan, L., Lawrence, R. S., \& Walker, P. (2002). How sustainable agriculture can address the environmental and human health harms of industrial agriculture. Environmental Health Perspectives, 110(5), 445-456.

Hsu, J. L., \& Wann, J. J.-W. (2004). Competitiveness and consumer preferences of U.S. fruits in Taiwan. Agribusiness, 20(4), 433-448.

Karelakis, C., Mattas, K., \& Chryssochoidis, G. (2008). Greek wine firms: Determinants of export performance. Agribusiness, 24(2), 275-297.

Kennedy, P. L., Harrison, R. W., \& Piedra, M. A. (1998). Analyzing agribusiness competitiveness: The case of the United State sugar industry. International Food and Agribusiness Management Review, 1(2), 245-257.

Liu, Z., Kemp, R. G. M., Jongsma, M. A., Huang, C., Dons , J. J. M., \& Omta, S. W. F. (2014). Key success factors of innovation projects of vegetable breeding companies in China. International Food and Agribusiness Management Review, 17(4), 177-204.

Lubell, M., Hillis, V., \& Hoffman, M. (2011). Innovation, cooperation, and the perceived benefits and costs of sustainable agriculture practices. Ecology and Society, 16(4), 23. http://dx.doi.org/10.5751/ES-04389-160423.

Lülfs-Baden, F.,Spiller, A., Zühlsdorf, A., \& Mellin, M. (2008). Customer satisfaction in farmer-to-consumer direct marketing. International Food and Agribusiness Management Review, 11(2), 49-72.

Martinez, M. G., \& Poole, N. (2004). Analysing linkages between strategy, performance, management structure and culture in the Spanish fresh produce industry. International Food and Agribusiness Management Review, 7(4), 16-39.

McElwee, G. (2008). A taxonomy of entrepreneurial farmers. International Journal of Entrepreneurship and Small Business, 6(3), 465-478.

Micheels, E. T., \& Gow, H. R. (2008). Market orientation, innovation and entrepreneurship: An empirical examination of the Illinois beef industry. International Food and Agribusiness Management Review, 11(3), 31-56.

Nag, R., Hambrick, D. C., \& Chen, M.-J. (2007). What is strategic management, really? Inductive derivation of a consensus definition of the field. Strategic Management Journal, 28(9), 935-955.

Nasir, V. A., \& Karakaya, F. (2014). Underlying motivations of organic food purchase intentions. Agribusiness, 30(3). 290-308.

Rankin, A., Gray, A. W., Boehljec, M. D., \& Alexander, C. (2011). Sustainability strategies in U.S. agribusiness: Understanding key drivers, objectives, and actions. International Food and Agribusiness Management Review, 14(4), 1-20.

Rogers, R. T., \& Caswell, J. A. (1988). Strategic management and the internal organization of food marketing firms. Agribusiness, 4(1), 3-10.

Rosairo, H. S. R., Lyne, M. C., Martin, S. K., \& Moore, K. (2012). Factors affecting the performance of farmer companies in Sri Lanka: Lessons for farmer-owned marketing firms. Agribusiness, 28(4), 505-517. 
Ross, R. B., Pandey, V., \& Ross, K. L. (2015). Sustainability and strategy in U.S. agri-food firms: An assessment of current practices. International Food and Agribusiness Management Review, 18(1), 17-48.

Russo, C., Cardillo, C., \& Perito, M. A. (2003). Product innovation and imperfect competition in the Italian fruit-drink industry. International Food and Agribusiness Management Review, 6(1), 70-83.

Smith, G. D., Arnold, D. R., \& Bizzell, B. G. (1985). Business strategy and policy. Boston, MA: Houghton Mifflin Harcourt.

Thompson, P. B. (2007). Agricultural sustainability: What it is and what it is not. International Journal of Agricultural Sustainability, 5(1), 5-16.

Torres, Jr., A., Akridge, J. T., Gray, A., Boehlje, M., \& Widdows, R. (2007). An evaluation of customer relationship management (CRM) practices among agribusiness firms. International Food and Agribusiness Management Review, 10(1), 36-60.

Westgren, R. E., \& Cook, M. L. (1986). Strategic management and planning. Agribusiness, 2(4). 477-489.

Westgren, R. E., Sonka, S. T., \& Litzenberg, K. K. (1988). Strategic issue identification among agribusiness firms. Agribusiness, 4(1), 25-37.

Yee, A. (2014). For the internet age, Taiwan's ICT industry needs a new model. East Asia Forum: Economics, politics and policy in East Asia and the Pacific. Retrieved December 16, 2014, http://www.eastasiaforum. org/2014/02/25/for-the-internet-age-taiwans-ict-industry-needs-anew-model/

Zahm, F., Viaux, P., Girardin, P., Vilain, L., \& Mouchet, C. (2007). From the concept of farm sustainability to case studies on French farms. In the proceedings and outputs of the first Symposium of the International Forum on Assessing Sustainability in Agriculture (INFASA, pp. 77-110), March 16, 2006, Bern, Switzerland.

\begin{abstract}
Polish)
Światowe rolnictwo przechodzi intensywne zmiany, które tworzq nowq rzeczywistość rynkowq, będqca znacznie bardziej złożonq i konkurencyjnq niż dotychczas. W celu zmierzenia się z tymi zmianami, niezbędna jest nowa perspektywa na praktyki zarzqdzania $w$ rolnictwie. Badania nad tym krytycznym zagadnieniem sq jednak ograniczone. Artykuł oferuje aktualne spojrzenie na zarzqdzanie strategiczne w przemyśle rolnym na Tajwanie poprzez pogłębione wywiady z 10 ekspertami agrobiznesu-przedsiębiorcami. Wyniki pozwoliły dokonać podziału strategii agrobiznesu w oparciu o trzy wymiary: otoczenie zewnętrzne, środowisko wewnętrzne i zrównoważony rozwój. Artykuł szczegółowo omawia każdy z wymiarów i identyfikuje pięć szerszych trendów w zarzqdzaniu strategicznym.
\end{abstract}

Słowa kluczowe: agrobiznes, agrobiznes przedsiębiorcy, zarzqdzanie strategiczne, zrównoważony rozwój. 


\section{Biographical notes}

Mr. Chao-Chien Chen received his M.S. degree in Business Management from Saiginaw Valley State University, Michigan, U.S.A, in 2003; and now enrols the Doctoral program of Bio-Industry Communication and Development at National Taiwan University, Taipei, Taiwan. He currently serves as a director at the Agriculture Information Communication Technology Enabling Office for the Council of Agriculture, Executive Yuan, Taiwan. His research interest focuses on agriculture e-marketing, agriculture innovation, and information communication. Chao-Chien Chen can be reached via markchen1204@gmail. com.

Dr. Hsiu-Ping Yueh is a Professor in the Department of Bio-Industry Communication and Development, National Taiwan University, Taipei, Taiwan. She gained her Ph.D. degree in the Instructional Systems at Pennsylvania State University, University Park, USA. Her research interests focus on: educational psychology, learning technology, professional education, performance technology, and human-computer interaction. Professor Yueh can be reached via yueh@ntu.edu.tw.

Dr. Chaoyun Liang is a Professor in the Department of Bio-Industry Communication and Development, National Taiwan University, Taipei, Taiwan. He gained his Ph.D. degree in the Instructional Systems Technology program at Indiana University, USA. His research interests focus on: imagination \& creativity, entrepreneurship \& social enterprise, and agrirural communication \& marketing. Professor Liang can be reached via cliang@ntu.edu.tw. 
